\title{
The Study of Green Human Resource Management and its effect on employees' health in Automobile Industry
}

\author{
Ms. Anuradha $a^{a^{*}}$, Dr. A.K. Srivastavab \\ aBharati Vidyapeeth Institute of Management \& Research, New Delhi, anunain92@gmail.com \\ ${ }^{*}$ Corresponding author.
}

Received: 18 October 2018, accepted: 19 October 2018, published: 3 March 2019

\begin{abstract}
As of late, there has been an expanding mindfulness inside business networks on the essentialness of making strides toward environmental friendliness and receiving different condition management methods. As the corporate world is going worldwide, the business is encountering a move from a regular money related structure to a cutting edge limit based economy which is prepared to investigate green financial aspects of business. Today, Green Human Resource Management (GHRM) has turned into a key business methodology for the noteworthy associations where Human Resource Departments have a functioning influence in making strides toward environmental friendliness at the workplace. The main objective of this study is to review Green Human Resource Management and its effect on Employees Health in Automobile Industry. This study focuses on how and why Green Human Resource Management practices are implemented by different organizations. This study also reviews the negative and positive impacts of green-HRM practices on employee health and the employee commitment levels in organizations.
\end{abstract}

Keywords: Green HRM, Employee Behaviour, Employee Health, Employee Commitment, green initiatives.

\section{INTRODUCTION:}

The term Green HRM has turned into the popular expression inside the business field at present and its noteworthiness is expanding complex with the progression of time. This term has additionally anchored position as an interesting issue in late research works since the mindfulness on natural management and supportable advancement has been progressively rising step by step all round the globe. Today the point Green HRM incorporates mindfulness toward ecological undertakings, as well as stands for the social and also sparing prosperity of both the association and the workers inside a more extensive prospect.

Marhatta and Adhikari, (2013) say that Green HRM is the utilization of HRM strategies to advance the manageable utilization of resources inside associations and, all the more for the most part advances the reasons for condition manageability".

Mathapati (2013) says that GHRM is specifically capable in making green workforce that comprehends, acknowledges, and rehearses green initiative and keeps up its green destinations all through the HRM procedure of enlisting, procuring, preparing, redressing, creating, and propelling the organizations human capital. 
Opatha and Arulrajah (2014) say that Green Human Resource Management alludes to the strategies, practices, and frameworks that make workers of the association green for the advantage of the individual, society, regular habitat, and the business.

Wehrmeyer (1996) says that Green human resources allude to utilizing each employee contact direct/interface toward advance feasible practices and increment employee mindfulness and commitments on the issues of manageability. It includes undertaking condition agreeable HR initiatives bringing about more prominent efficiencies, bring down expenses and better employee commitment and maintenance which thusly, assist associations with reducing employee carbon impressions by any semblance of electronic documenting, auto sharing, work sharing, remotely coordinating and virtual meetings, reusing, working from home, internet preparing, vitality proficient office spaces and so on. In this green world the green HR or individual's management work has maintainability at its center as a feature of its kin management and ability management center and associations draw in with the general public by adjusting their plans to it. Networks, clients and contractual workers all wind up break even with partners alongside employees and investors.

\section{LITERATURE REVIEW :}

\subsection{Green HRM initiatives:}

Mampra (2013) characterizes Green HRM as the utilization of HRM strategies to empower the supportable utilization of resources inside business undertakings and advance the reason for environmentalism which additionally helps up worker spirit and fulfillment. Others portray Green HRM as the utilization of HRM arrangements, methods of insight, and practices to advance maintainable utilization of business resources and impede any untoward damage emerging from ecological worries in associations (Zoogah, 2011).

Mandip (2012) says that Green initiatives inside HRM shape some portion of more extensive projects of corporate social obligation. Green HR basically comprises of two noteworthy components to be specific condition agreeable HR hones and the conservation of information capital. Inside an association, human resource and their frameworks are the fundamental establishment of any business, be it money related business or practical business. They are the ones in charge of arranging and executing those eco-accommodating strategies to make a green environment. They contend that without encouraging the human resource and executing manageable strategies, becoming environmentally friendly would be a hard nut to separate. Despite the fact that a considerable degree of existing writing manages the theme of Green HRM, there is still vagueness related with the compelling execution of green HR management arrangements in associations round the globe to achieve total green corporate culture. This article grasps how companies are taking initiatives to support condition management program by creating human resource arrangements and discover diverse procedures engaged with green HRM based on surviving writing in the zone. Further, they proceed onward to checking on the writing on the HR parts of GHRM, which helps in recognizing how enterprises today create human resource approaches for making strides toward environmental friendliness. The investigation additionally expects to give streamlined understanding on some regular GHRM procedures and endeavors to propose some green initiatives for HR.

Lado and Wilson (1994) characterizes HRM framework as an arrangement of unmistakable however interrelated exercises, capacities, and process that intends to draw in, create, and keep up a company's human resource. Associations by and large sort out HR rehearses into frameworks that are reliable with their way of life and business methodology (Boselie et al., 2001).

Daily, Bishop, and Govindarajulu, (2009) state that green initiatives incorporated into HRM pronouncement is a piece of corporate social obligation over the long haul. Today, associations are executing and incorporating green initiatives in their plan with the assistance of their human resource. Directors ensure that their HR is using green human resource rehearses in suitable way. As an addendum to the announcement, a few authors have recommended that it is imperative to advance a lot of specialized and management aptitudes among all workers of the association keeping in mind the end goal to execute a successful corporate green management framework in organizations (Unnikrishnan and Hegde, 2007).

Sathyapriya, Kanimozhi, and Adhilakshmi (2014) say that associations over the world are consolidating and progressing in the direction of actualizing GHRM practices to increase upper hands among the corporate world. Finish appropriation and coordination of GHRM in business isn't outlandish yet requires a changed approach toward the current HR hones on part of both the management and in addition representatives all the while. A key part for HR ecological officials could be to rule directors as far as increasing full staff co-task toward actualizing natural arrangements which implies HR needs to sustain supporters and make systems of issue solvers willing to act to change the present the norm. There are various 
issues identified with GHRM that will be considered by HR office before actualizing green initiatives and, every one of them can be not contained inside a solitary archive.

\subsection{Green HRM outcomes- Impact on employee behavior:}

Deshwal (2015) says that promoting 'eco-intrapreneurs' to enhance association's items as well as administrations with effective usage of existing budgetary, human and regular resources. Empower the representatives for contribution and interest in the social and natural initiatives. Green proposal plans and issue shooting circles ought to be produced through representative inclusion and cooperation. Organizations will create green work environment which is naturally touchy, resource productive and socially dependable. Green driving propensities like flexi-hours, auto pooling, free or marked down transportation passes, and so on ought to be presented. Arrangement of telecommunicating or e-work to decrease travel and outflow, Promoting green printing by diminishing paper and toner use and Adopting '3R' approach of 'Lessen Recycle-Reuse' resources, Building up center gatherings as Low carbon-boss (counting CEO and Board) for green initiatives provide 'green whistle blower' help-lines notwithstanding this the organizations executing worker health programs.

Employee relations are that part of HRM which is worried about building up agreeable business employee relationship. The relationship encourages inspiration and confidence of the employees and additionally, builds the efficiency. Fundamentally, employee relations include employee interest and strengthening exercises. It additionally forestalls and resolve issues emerged at working environment that may influence the work. Actually, positive employee relations are an immaterial and persisting resource and a wellspring of upper hand for any association. Employee interest in Green initiatives expands the odds of better green management as it adjusts employees' objectives, abilities, inspirations, and observations with green management practices and frameworks. Including employees in EM has been accounted for as enhancing EM frameworks, for example, effective resource use (Florida and Davison, 2001); decreasing waste (May and Flannery, 1995); and lessening contamination from working environments (Kitazawa and Sarkis, 2000). A few laborers in their investigation inferred that individual strengthening emphatically impacts efficiency and execution, and encourage restraint, singular reasoning, and critical thinking aptitudes (Renwick, 2008; Wee and Quazi, 2005).

\subsection{Impact on employee health- Critical perspectives:}

From a miniaturized scale point of view, HRM is conjointly connected to individual and inside authoritative components, for example, rare resources, employee practices, maturing workforces and business related health issues. Having a HRM framework that encourages maintainability enables firms to address the previously mentioned issues while holding an excellent workforce (Ehnert and Harry, 2012).

An ongoing report by Wagner (2012) investigated green HRM and whether its execution at the authoritative level is probably going to drive EMS usage. The longitudinal investigation found that employees who are happy with the natural procedures of their association effectively drive key incorporation of socially related issues, for example, work-life adjust, and health and wellbeing programs. The involvement of HR in the green HRM execution process is basic, in view of its help through useful employee associations. By utilizing different types of conveyed dispatch, (for example, coordinate/backhanded, verbal and print), HRM can clearly demonstrate to employees how the association is tending to natural issues and concerns. Accordingly, there is a more noteworthy probability that employees will straightforwardly show bolster for the associations ecological or potentially socially mindful initiatives, with worry for the earth likewise more prone to end up an essential thought to them.

Ones and Dilchert (2012) assert that with a specific end goal to do this it is important to comprehend what it is alluded to when we talk about employee green practices. Right off the bat, it is fundamental to feature the contrasts between socially dependable and natural results. Authoritative social initiatives are executed to enhance the wellbeing and health of employees, advancing assorted variety and decidedly adding to social issues, though ecological initiatives plan to enhance an association's maintainability and naturally related results. It is critical to comprehend what recognizes these two ideas, as it empowers scientists to characterize particular employee conduct composes (i.e. green), and pick the suitable instrumentality (green HRM) to persuade, prepare and remunerate employee work environment practices.

\subsection{Impact on employee commitment- Critical perspectives:}

In each association the businesses are the way to switch on the objective or target what we have to build up. So the dedication of the specialist in the recently doled out work in real basic part to draw a photo what we anticipate. For that 
corporate should influence the representative to give careful consideration on the objective what we to need to execute. The level of adequacy and time utilization for the objective achievement absolutely relies upon the workers duty. In the reason for condition laborers responsibility we will achieve this objective with no obstacles if the citizenship conduct is one of the dispositions of our specialist. The capacity and commitments of the staffs in the unbeaten course of action in addition to mix of condition conduct inside the arranged yearn of the organization must be consider. It has been suggested that engaging with workers in coordinate natural fear is the absolute most vital stage confronting organizations at display and in the up and coming days. (Frank, Finnegan, and Taylor, 2004). This should clarify why workers commitment in the district of environmental supervision is fine examined and grounded in idea (Renwick et al., 2012). Author has recognized the essentialness of laborers occupied with the execution of biological methodologies (Ramus and Steger, 2000). Why business select to include the work drive in environmental organization is thus fine revealed (AragonCorrea et al., 2013; Brio et al., 2007, 2009). Workers commitment in environmental management has trio center: right off the bat completely through tapping laborers' implicit information obtain through the specific close relationship to the assembling procedure (Boiral, 2002); next by engaging and additionally approving laborers to make proposals for biological advancement (Govindarajulu and Daily, 2004) and next by enhancing human advancements in the work environment, which bolster natural improvement endeavors.

James (1996) says that a vital manner by which employee involvement and investment can be empowered inside the association is to look for business people inside the organization who are socially or environmentally situated known as eco-ambitious innovators. They can sort out existing monetary, human and regular resources in a way that increases the value of the company's items or administrations where it didn't exist beforehand. Aside from this employee involvement (EI) groups in EM can cut waste (as employees are believed to have the most information of the work procedures and items included); can oversee such complex function admirably; and utilizing them helps fabricate employee pride and commitment in their work. El groups cannot just realize an adjustment in how function forms are performed, yet additionally enhance labourer wellbeing and security as well. American Airlines guarantee their flight orderlies reuse more than 616,000 pounds of aluminium jars, acquiring in any event $\$ 40,000$ to them in one year, and Dow Chemical's Waste Reduction (WRAP) program was set up as a challenge for all employees to draw in with, and from which Dow assert a 173 for every penny Return on Investment (ROI) from their first year of task. Eco-initiatives happen from inventive thoughts from all employees, and thus systems should be made to include employees in it - which incorporate giving a part for directors in giving employees autonomy to produce innovative answers for take care of issues (which empowers their ecological management concern), and make best utilization of applying their abilities. An El approach in EM inspires the laborer, enables them to recognize issues like spillages in the procedure of creation, and that appointing obligations to workers depends on group learning of the reasons for waste and how to lessen them as observed in El in squander decrease at Kodak, DuPont, and Procter and Gamble.

The two key additions from presenting Green El initiatives are believed to be upgrades in ecological and specialist wellbeing, and the advancement of more educated employees and supervisors (Milliman and Clair, 1996). The discoveries recommend that employees should be engaged with defining natural methodology, so they can make and grow the information expected to advertise "green" products (Oates, 1996). Associations are urging employees to consider thoughts to lessen carbon discharges and spare vitality. An ongoing HSBC activity in the U.K. discovered advantages in carbon sparing apparently coming from employee initiatives including one where staffs at first direct can get trash from home and reuse it at work. The utilization of Employee Participation (EP) in EM has been noted to help keep contamination from workplaces (Ramus, 2001).

EP influences a commitment to enhancing natural execution as employees to have information and aptitudes that chiefs lack. There are two manners by which the workers can take an interest on ecological activities: a recommendation program and critical thinking circles wherein the pro staffs is more associated with venture inception while line level workers will probably partake in venture usage. Different manners by which employees can be urged are to seek after green driving propensities like permitting adaptable work weeks, building up an auto pool-program, offering free or marked down free transportation passes, including auto sharing as an employee advantage and setting up transportation investment account. One of the significant changes in the HR approach has been the development of working from home or e-work a game plan whereby workers perform errands for their bosses by means of a media transmission interface at their home which diminishes the cost of driving both in rupees or dollars and outflows.

\subsection{Framework and Propositions:}


The following figure illustrates the conceptual framework for the study of green human resource management and its effect on employees' health in automobile industry.

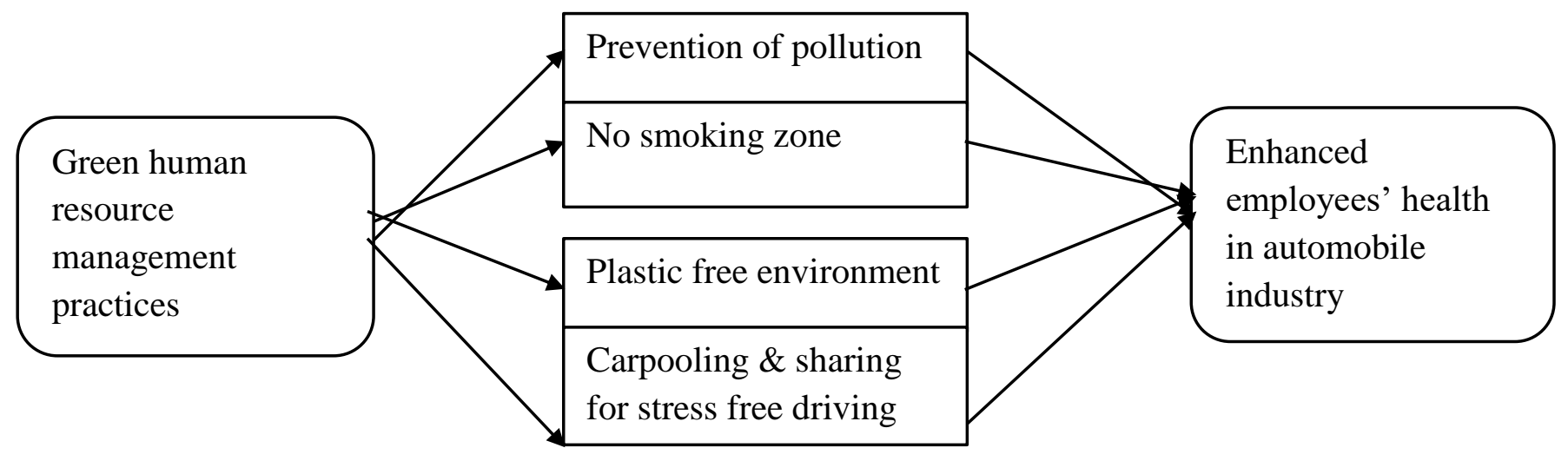

\section{Propositions:}

- Null Hypothesis: Prevention of pollution is not a green human resource management practices that leads to enhanced employees' health in automobile industry

Alternative Hypothesis: Prevention of pollution is a green human resource management practices that leads to enhanced employees' health in automobile industry

- Null Hypothesis: No smoking zone is not a green human resource management practices that leads to enhanced employees' health in automobile industry

Alternative Hypothesis: No smoking zone is a green human resource management practices that leads to enhanced employees' health in automobile industry

- Null Hypothesis: Plastic free environment is not a green human resource management practices that leads to enhanced employees' health in automobile industry

Alternative Hypothesis: Plastic free environment is a green human resource management practices that leads to enhanced employees' health in automobile industry

- Null Hypothesis: Carpooling \& car sharing for stress free driving is not a green human resource management practices that leads to enhanced employees' health in automobile industry

- Alternative Hypothesis: Carpooling \& car sharing for stress free driving is a green human resource management practices that leads to enhanced employees' health in automobile industry

\section{FINDINGS:}

The examination found there were contrasts in apparent positive results from executing Green HR Practices. From this study, it is observed that, prevention of pollution, no smoking zone, plastic free environment, carpooling \& car sharing for stress free driving are the factors that have ability to enhance the employees' health in automobile industry. Indeed, the measure of an organization may affect the achievement of various advantages and on the obstacles confronted while actualizing Green HR Practices. Substantial organizations have settled structure and offices and resources to actualize 
these practices successfully and effectively. Small and medium estimated organizations by and large need resources, the capital, and top management support to actualize Green HR Practices.

\section{CONCLUSION :}

The effect of our everyday exercises on living condition causes consumption of normal resources and an unnatural weather change. This acknowledgment activated people to become environmentally friendly as well as associations. The globally growing concern on ecological balance influenced organizations to focus on detailing and executing green strategies in the association. Organizations began moving towards their objectives with green awareness of other's expectations. Human Resource management with green touch is turning into the power of natural manageability by embracing eco-accommodating practices and arrangements. Green HRM is one such huge territory of management that attempts to achieve supportability. Green HRM of an association results in an expansion of efficiency and lessens wastage. It is corporate judiciousness and financially savvy practice to hold workers for new employments than discharging and enlisting new ones. Green HRM began with the expect to build up the eco-accommodating nature inside them and the preview of the authoritative setup, by creating HR arrangements and the systems, with a specific end goal to accomplish the authoritative objective. Extent of the investigation had been checked on the examinations made with the HR gathering and the business' employees inside the vehicle part which have been taken with the end goal of the audit.

Table: 1 Related works on GHRM.

\begin{tabular}{|c|c|c|c|}
\hline S.no & Author & Year & Related work \\
\hline 1. & Mello et al & 2016 & $\begin{array}{l}\text { The primary aim of his exploration is to survey the } \\
\text { level of practices of green HRM among employees. } \\
\text { The primary target is to know the noteworthiness on } \\
\text { green human resource management and } \\
\text { comprehend the employee's recognition towards } \\
\text { the awareness of environmental issues in work } \\
\text { environment. This investigation is done } \\
\text { fundamentally on the essential information choosing } \\
50 \text { tests with straightforward irregular inspecting } \\
\text { technique and furthermore optional information. }\end{array}$ \\
\hline 2. & Bon et al & 2018 & $\begin{array}{l}\text { The point of this examination is to audit the different } \\
\text { writings on the connection between GHRM hones, } \\
\text { GSCM practices and maintainability execution. } \\
\text { Besides, this investigation intends to propose a } \\
\text { sensible reasonable model to illuminate the } \\
\text { connection between these three factors with } \\
\text { regards to Palestinian assembling part. The } \\
\text { examination discoveries will be particularly basic for } \\
\text { assembling associations with the point of enhancing } \\
\text { their manageability. }\end{array}$ \\
\hline 3. & Sriram and Suba & 2017 & $\begin{array}{l}\text { This Study focuses on the impact of green human } \\
\text { resource management (G-HRM) practices over } \\
\text { organization effectiveness. }\end{array}$ \\
\hline
\end{tabular}




\begin{tabular}{|c|c|c|c|}
\hline 4. & Ahmad & 2015 & $\begin{array}{l}\text { The paper to a great extent centers upon the } \\
\text { different Green Human Resource Practices sought } \\
\text { after by the associations everywhere throughout the } \\
\text { world and, clarifies the improved significance of } \\
\text { GHRM. The investigation likewise adds to the } \\
\text { surviving writing by talking about future heading of } \\
\text { some GHRM capacities. At long last, the paper } \\
\text { recommends some possibly productive HR initiatives } \\
\text { for Green associations. }\end{array}$ \\
\hline 5. & Menon & 2016 & $\begin{array}{l}\text { This paper chiefly center to expedite mindfulness } \\
\text { among the businesses Green HR, accordingly helping } \\
\text { the associations and its kin, to comprehend the } \\
\text { natural related issues and lessen ecological issues, } \\
\text { risks and contaminations. The employees in the } \\
\text { associations must understand the significance of } \\
\text { Green development, Green Audit and Green HR. }\end{array}$ \\
\hline 6. & Dumont & 2015 & $\begin{array}{l}\text { This paper focused on the Green Human } \\
\text { Management and employee workplace outcomes. }\end{array}$ \\
\hline 7. & Jafri & 2012 & $\begin{array}{l}\text { This paper has presented survey analysis of the } \\
\text { status of green HR practices in certain automobile } \\
\text { industries of India. The study found that there were } \\
\text { differences in perceived positive outcomes from } \\
\text { implementing green HR practices. }\end{array}$ \\
\hline 8. & Jain & 2016 & $\begin{array}{l}\text { This study found that understanding and increasing } \\
\text { the scope and depth of green HRM practices, } \\
\text { organizations can improve their environmental } \\
\text { performance in a more sustainable manner than } \\
\text { before. The green HRM practices are more powerful } \\
\text { tools in making organisations and their operations } \\
\text { green. The green performance, green behaviours, } \\
\text { green attitude, and green competencies of human } \\
\text { resources can be shaped and reshaped through } \\
\text { adaptation of green HRM practices. }\end{array}$ \\
\hline 9. & Masri & 2016 & $\begin{array}{l}\text { This study discussed the role of GHRM in creating a } \\
\text { green culture and achieving employee management } \\
\text { goals which will improve employee performance. } \\
\text { The results of hypotheses testing show that there is } \\
\text { a statistically significant relationship between GHRM } \\
\text { practices and employee performance. }\end{array}$ \\
\hline
\end{tabular}




\begin{tabular}{|l|l|l|}
\hline 10. & Uddin & $\begin{array}{l}\text { The discoveries of the examination envelop the level } \\
\text { of green HRM rehearses embraced by the managing } \\
\text { an account segment of a creating nation where the } \\
\text { greater part of the organizations tested know about } \\
\text { the Green HRM yet the practices are not as much as } \\
\text { what is required. This examination additionally } \\
\text { found that, the appropriation of Green practices has } \\
\text { a positive association with expanded authoritative } \\
\text { execution and advances association's picture. It is } \\
\text { normal that the investigation would assist the } \\
\text { enterprises with gaining a grip on the most proficient } \\
\text { method to transform customary HRM rehearses into } \\
\text { Green ones so as to harvest the products of Green } \\
\text { HRM in this 21st century. }\end{array}$ \\
\hline
\end{tabular}

\section{REFERENCES}

Marhatta, S., \& Adhikari, S. (2013). Green HRM and sustainability. International eJournal Of Ongoing Research in Management \& IT. Retrieved from

Mathapati, C. M. (2013). Green HRM: A strategic facet. Tactful Management Research Journal, 2(2), 1-6.

Opatha, H. H., \& Arulrajah, A. A. (2014). Green Human Resource Management: Simplified general reflections. International Business Research, 7, 101-112.

Wehrmeyer, W. (1996). Greening people: Human resources and environmental management. Sheffield: Greenleaf.

Mampra, M. (2013, January 6-9). Green HRM: Does it help to build a competitive service sector? A study. In Proceedings of tenth AIMS International Conference on Management (pp. 1273-1281). Retrieved from

Mandip, G. (2012). Green HRM: People management commitment to environmental sustainability. Research Journal of Recent Sciences, 1, 244-252.

Lado, A. A., \& Wilson, M. C. (1994). Human resource systems and sustained competitive advantage: A competency based perspective. Academy of Management Review, 19, 699-727.

Boselie, P., Paauwe, J. and Jansen, P. Human Resource Management and Performance: Lessons From The Netherlands. The International Journal of Human Resource Management 12 (7) (2001) 1107-1125.

Daily, B. F., Bishop, J. W., \& Govindarajulu, N. (2009). Conceptual model for organizational citizenship behavior directed toward the environment. Business \& Society, 48, 243-256.

Unnikrishnan, S., \& Hegde, D. S. (2007). Environmental training and cleaner production in Indian industry- A micro-level study. Resources Conservation and Recycling, 50, 427-441.

Sathyapriya, J., Kanimozhi, R., \& Adhilakshmi, V. (2014). Green HRM-Delivering high performance HR systems. International Journal of Scientific Research, 3, 31-34. 
Deshwal, D. (2015). Green HRM: An organizational strategy of greening people. International Journal of applied research, $1(13)$, pp. 176-181.

Florida, R., \& Davison, D. (2001). Gaining from Green Management: Environmental management systems inside and outside the factory. California Management Review, 43, 64-84.

May, D. R., \& Flannery, B. L. (1995). Cutting waste with employee involvement teams. Business Horizons, 38, 28-38

Kitazawa, S., \& Sarkis, J. (2000). The relationship between ISO 14001 and continuous source reduction programs. International Journal of Operations and Production Management, 20, 225-248.

Renwick, D. (2008). Green HRM: A review, process model, and research agenda (Discussion Paper Series). The University of Sheffield. Retrieved from http://www.shef.ac.uk/content/1/c6/08/70/89/2008-01.pdf

Wee, Y. S., \& Quazi, H. A. (2005). Development and validation of critical factors of environmental management. Industrial Management \& Data Systems, 105, 96-114.

Ehnert, I., \& Harry, W. (2012). Recent developments and future prospects on sustainable human resources management: Introduction to the special issue. Management Revue, 23(2), 221-238.

Wagner, M. (2012). 'Green' human resource benefits: Do they matter as determinants of environmental management system implementation? Journal of Business Ethics, 114(3), 443-456.

Ones, D. S., \& Dilchert, S. (2012). Environmental sustainability at work: A call to action. Industrial and Organisational Psychology, 5(4), 444-466.

Frank, F., Finnegan, R. \& Taylor, C. (2004). The Race for Talent: Retaining and Engaging Workers in the 21st Century. Human Resource Planning. 27 (3): $12-26$

Renwick, D. W.S., Redman, T., \& Maguire, S. (2013). Green Human Resource Management: A review and research agenda. International Journal of Management Reviews, 15(1), 1-14.

Ramus, C. A., \& Steger, U. (2000). The roles of supervisory support behaviours and environmental policy in employee "eco-initiatives" at leading-edge European companies. Academy of Management Journal, 43(4), 605-626.

Aragon-Correa, J.A., Martin-Tapia, I. and Hurtado-Torres, N.E. Proactive (2013). Environmental Strategies and Employee Inclusion: The Positive Effects of Information Sharing and Promoting Collaboration and The Influence of Uncertainty. Organization \& Environment 26 (2) 139-161

Brio, J.A. del, Fernandez, E. and Junquera, B. (2007). Management and Employee Involvement in Achieving an Environmental Action-Based Competitive Advantage: an Empirical Study. The International Journal of Human Resource Management 18 (4) 491-522.

Boiral, O. (2002) . Tacit Knowledge and Environmental Management. Long Range Planning 35 (3) 291-317.

Govindarajulu, N., \& Daily, B. F. (2004). Motivating employees for environmental improvement. Industrial Management \& Data Systems, 104, 364-372.

James, P., (1996) . Total Quality Environmental Management and Human Resource Management, in Wehrmeyer, W. (ed) (1996), 35-48

Milliman, J. and Clair, J., Best Environmental HRM Practices in the US, in Wehrmeyer, W. (ed) (1996), 49-73, (1996)

Oates, A., (1996) Industrial Relations and the Environment in the UK, in Wehrmeyer, W. (ed) (1996), 117- 140.

Ramus, C.A., (2001). Organizational Support for Employees: Encouraging Creative Ideas for Environmental Sustainability, California Mgmnt Review, 43(3) 85- 105. 
Mello, D.L., Manjush, H.H., and Monterio, M. (2016). A study on the green human resource management at gateway hotel, Mangalore. International Journal of scientific research and Modern education, 1(1), pp. 843-852.

Bon, T.A., Zaid, A., Jaaron, M.A.A (2018). Green human resource management, green supply chain management practices and sustainable performance. The International Conference on Industrial Engineering and Operations Management, At Bandung, Indonesia. Retrieved from https://www.researchgate.net/publication/323257955_Green_human_resource_management_Green_supply_ch ain_management_practices_and_Sustainable_performance

Sriram, P.V., and Suba, M. (2017). Impact of green human resource management (G-HRM) practices over organization effectiveness. Journal of Adv Research in Dynamical \& control systems, 07 special issue on management studies, pp. 386-394.

Ahmad, S. (2015). Green human resource management: Policies and practices. Cogent business \& management. 2(2015), pp. 1-13.

Menon, B., (2016). A study of green HR practices and strategic implementation in the Kolhapur based industries. Indian streams research journal, 6(2), pp. 1-8.

Dumont, J. (2016). Green human resource management and employee workplace outcomes. Retrieved from http://search.ror.unisa.edu.au/media/researcharchive/open/9916068899001831/53132374380001831

Jafri, S. (2016). Green HR practices: an empirical study of certain automobile organizations of India. Human resource management. 42(2012), pp. 6193-6198.

Jain, A. (2016). Green Human Resource Management concept in Indian Industries- Present scenario. International Journal of Multidisciplinary Allied research Review and Practices. 3(7), pp. 171-181.

Masri, A.H. (2016). Assessing green human resources management practices in west bank: An explanatory study. Retrieved from https://scholar.najah.edu/sites/default/files/Hiba\%20Awad\%20Masri_0.pdf

Uddin, M. (2018). Practicality of green human resource management practices: A study on banking sector in Bangladesh. International Journal of economics, commerce and management. VI(6), pp. 382-393.

Tang, G., Chen, Y., Jiang, Paille, P., and Jia, J. (2017). Green human resource management practices: scale development and validity. Asia pacific journal of human resources, 56(1). 